\title{
Título da página eletrónica: La’o Hamutuk
}

URL: http://www.laohamutuk.org/index.html

\section{Paula Duarte Lopes}

\section{(2) OpenEdition \\ Journals}

Edição electrónica

URL: http://journals.openedition.org/rccs/5755

DOI: $10.4000 /$ rccs. 5755

ISSN: 2182-7435

\section{Editora}

Centro de Estudos Sociais da Universidade de Coimbra

\section{Edição impressa}

Data de publição: 1 setembro 2014

Paginação: 187

ISSN: 0254-1106

Refêrencia eletrónica

Paula Duarte Lopes, "Título da página eletrónica: La'o Hamutuk 》, Revista Crítica de Ciências Sociais [Online], 104 | 2014, posto online no dia 23 setembro 2014, consultado o 22 setembro 2020. URL : http://journals.openedition.org/rccs/5755; DOI : https://doi.org/10.4000/rccs.5755 


\section{Espaço Virtual}

\section{Título da página eletrónica: La'o Hamutuk URL: http://www.laohamutuk.org/index.html}

A organização não governamental $L a^{\prime} O$ Hamutuk foi criada em 2000 e o seu nome significa, literalmente, 'caminhando juntos', refletindo o seu propósito de contribuir para uma participação efetiva da população timorense nos esforços de reconstrução e desenvolvimento do país. Para esse efeito, monitoriza e analisa a presença das principais instituições internacionais em Timor-Leste no que diz respeito ao processo de desenvolvimento físico, económico e social no país. Para além de uma seç̧ão extremamente completa de documentos relativos à presença das Nações Unidas em Timor-Leste, incluindo resoluções, relatórios e cartas oficiais, esta página inclui também relatórios da própria organização sobre diversos temas. Existem ainda vários textos de opinião que alertam para diferentes dinâmicas atuais e muitas vezes contêm referências a fontes políticas, económicas e sociais que permitem aprofundar, complementar e/ /ou triangular a pesquisa. Existem muitas organizações não-governamentais timorenses atualmente, mas a singularidade da La'o Hamutuk é constituir um centro de recursos, disponibilizando informação pertinente, mas facultando também uma abordagem crítica quer aos esforços timorenses como aos das organizações internacionais em Timor-Leste, apresentando ideias e modelos alternativos por pessoas com experiência prática sobre estes temas. A esmagadora maioria da informação está em inglês, mas também se conseguem encontrar algumas páginas traduzidas para tétum.

\section{Título da página eletrónica: Luta Hamutuk URL: http://www.lutahamutukinstitute.org/}

Luta Hamutuk significa 'lutando juntos'. Esta organização não governamental foi criada em 2005 por ativistas empenhados em ter um contributo ativo para assegurar um desenvolvimento participativo e responsável em Timor-Leste. Para esse efeito monitorizam de forma atenta a construção e execução do orçamento de Estado, produzindo boletins mensais com informação relevante, por vezes focada em projetos concretos nas áreas da educação, saúde, apoio a veteranos ou rede rodoviária; acompanham o progresso dos relatórios da Iniciativa da Transparências nas Indústrias Extrativas (uma coligação global de governos, companhias e sociedade civil) e da sua implementação, disponibilizando boletins mensais de informação relativos ao fundo de petróleo timorense e documentos sobre questões associadas à exploração de petróleo e gás para divulgação de informação nas comunidades locais; e desenvolvem atividades ao nível dos distritos e subdistritos, apresentando informação, treinando pontos de contacto nessas comunidades bem como os seus líderes, e desenvolvendo investigação nalguns projetos específicos sobre infraestrutura comunitária. Toda a informação disponível na página oficial da Luta Hamutuk pretende 
contribuir para a autodeterminação do povo timorense, promovendo justiça económica e participação pública, com base em valores democráticos, de igualdade e transparência. Consequentemente, muita da informação disponível encontra-se em tétum, mas também existe informação em inglês que permite conhecer os diferentes projetos comunitários, os resultados da monitorização efetuada e as iniciativas desenvolvidas.

\section{Título da página eletrónica: ReliefWeb URL: http://reliefweb.int/organization/unmit}

ReliefWeb é um serviço digital especializado do Gabinete de Coordenação dos Assuntos Humanitários das Nações Unidas (OCHA) criado em 1996. Apesar de ser uma página bastante específica, constitui uma fonte de informação extremamente relevante, uma vez que faculta informação fiável e atempada sobre crises em diferentes partes do mundo, incluindo Timor-Leste. Em momentos de crise é muitas vezes difícil saber o que se está a passar no terreno de forma atempada e com confiança, pois encontram-se reportagens contraditórias, de fontes pouco fiáveis e muitas vezes a informação só é conhecida depois dos acontecimentos. ReliefWeb permite obter informação crucial para avaliar diferentes situações de crise e contribuir para uma planificação de ajuda mais ajustada à realidade local, coligindo informação jornalística, informação de diversas organizações internacionais e nacionais, disponibilizando relatórios sobre a situação em diferentes locais do mundo e de acompanhamento e avaliação desses mesmos casos. Timor-Leste já não aparece como um país em crise, mas para além de toda a informação histórica disponível, a organização continua a monitorizar a situação em Timor-Leste, facultando informação atualizada sobre aspetos que podem evoluir para situações de crise ou instabilidade por motivos económicos, sociais ou mesmo de saúde pública. A página é uma excelente plataforma de informação sobre Timor-Leste, bem como sobre outros países que viveram ou estão a viver um período de violência disseminada no seu território. Toda a informação está disponível na sua esmagadora maioria em inglês.

\section{Título da página eletrónica: International Crisis Group - Crisis Watch URL: http://www.crisisgroup.org/en/publication-type/crisiswatch.aspx}

A organização internacional não-governamental International Crisis Group (ICG) foi criada em 1995 com o objetivo de contribuir para a prevenção e gestão pacífica de conflitos violentos. O seu método de trabalho é distinto de várias outras organizações por basear os seus relatórios em trabalho próprio de investigação e apuramento de factos nos países sob análise, para além de se empenhar num processo de apoio, promoção e defesa de políticas que previnam e contribuam para a gestão pacífica de conflitos violentos junto de decisores políticos nos centros internacionais mais relevantes bem como nas regiões onde trabalham. Mais, o ICG procura identificar os fatores necessários à mudança e os atores que podem ativar e/ou influenciar esses fatores, sejam eles políticos, legais, financeiros ou mesmo militares. Assim, para além da informação factual e dos relatórios da investigação realizada e respetiva análise, 
uma preciosa mais-valia desta página são os relatórios com recomendações políticas. A credibilidade política e científica do trabalho do ICG é baseada na qualidade da investigação desenvolvida. Uma das publicações mais acessíveis e de fácil leitura é o CrisisWatch - um boletim mensal dirigido à comunidade política, aos meios de comunicação social, ao mundo empresarial e ao público em geral com uma atualização regular sucinta do ponto de situação nos locais mais relevantes de conflito, ou potencial conflito, violento no mundo. Toda a informação está disponível em inglês, mas há também uma grande quantidade de informação disponível em francês e árabe, bem como uma menor quantidade em outros idiomas.

\section{Título da página eletrónica: Insight on Conflict URL: http://www.insightonconflict.org/about/}

Insight on Conflict é uma publicação sobre esforços locais de construção e consolidação da paz no mundo associada à organização internacional não governamental Peace Direct, fundada em 2002. A informação desta página parte de uma perspetiva de baixo para cima, uma vez que se baseia em informação local, e não é dirigida especificamente a académicos ou mesmo a especialistas. O objetivo é essencialmente disseminar relatos de pessoas envolvidas localmente em esforços de construção e consolidação da paz junto do público em geral. A ideia é proporcionar informação que permita estabelecer contactos, contribua para investigação e permita um melhor entendimento do impacto potencial do trabalho de atores locais na construção e consolidação da paz. A Peace Direct pretende ajudar a alterar o equilíbrio de poderes e recursos no mundo em favor dos que detêm um conhecimento local profundo sobre um determinado conflito violento e as suas causas, a autoridade moral para desafiar as pessoas a mudarem, e o empenho de longo-prazo necessário para promover uma paz sustentável. Ao relatarem histórias, iniciativas e projetos de atores locais, o Insight on Conflict dá voz aos que normalmente não a têm. Mais de metade das organizações locais mencionadas na publicação não têm páginas eletrónicas. O Insight on Conflict torna visível e acessível informação sobre atores locais relevantes para processos de construção e consolidação da paz. As atividades destes atores devem incidir na cessação da violência e de conflitos destrutivos e na promoção de uma paz justa e sustentável e têm de ser imparciais e apartidários, ou seja, não podem apenas trabalhar com uma das fações envolvidas no conflito violento. Esta página é uma fonte de informação crucial para quem trabalhe sobre a temática da construção e consolidação da paz, incluindo ou centrando-se numa perspetiva local desta dinâmica. A informação recolhida baseia-se numa vasta rede de correspondentes. A informação é disponibilizada em inglês.

Paula Duarte Lopes 
